\title{
ABDURRAHMAN ÖMERİ (Ö. 1933) VE AILE HUKUKUNA DAİR MECELLE ÇALIŞMASI
}

\author{
İBRAHIM MARAŞ*
}

Öz: Ahmet Cevdet Paşa'nın (ö. 1895) başkanlığında hazırlanan Mecelle-i Ahkâmı Adliye adlı meşhur eserin Kazan bölgesindeki ceditçilik hareketine önemli bir tesiri bulunmaktadır. Mecelle, bölgedeki bazı medreselerde ders kitabı olarak da okutulmuştur. Kazan bölgesindeki dinî yapılanma hiyerarşik bir yapıda değildi. Çarlık Rusya'sında Müslümanlar miras, evlenme ve boşanma gibi meselelerini kendileri çözmeye uğraşıyorlardı. Bölgede her mahalledeki imamlar, aynı zamanda kadılık görevini icra ediyorlardı. Bu da verilen dinî hükümlerde ciddi farklılıklara neden oluyordu. Bu yüzden Osmanlı Mecelle'si gibi kodifike edilmiş hükümlerden oluşan bir el kitabı temel ihtiyaçtı. Bunu göze alan İdil-Ural Müslümanları aile hukuku alanında yeni bir mecelle yazılması gerektiğini savunmuşlardır. Çünkü İdil-Ural bölgesi Müslümanlarının temel ihtiyacı, aile hukuku alanındaydı. Hâlbuki Ahmet Cevdet Paşa başkanlığında hazırlanan Mecelle'de aile hukuku bölümü bulunmuyordu.

1917'deki Ulema Nedvesi toplantısında dönemin müftüsü Âlimcan Barûdi başkanlığında bir Mecelle hazırlanması doğrultusunda Ufa'daki müftülükte danışma meclisi oluşturulmuştur. Ancak dönemin şartları gereği bu ciddi adımlar da sonuçsuz kalmıștır. Bugüne kadar bu konuda Ufa'daki Diniye Nezareti bünyesinde bir Mecelle hazırlanıp hazırlanmadığı bilinmemekteydi. Meşhur âlim Abdurrahman Ömeri'nin el yazmalarının tasnif ve kataloğunun hazırlanması tarafımızdan yapılmıştı. Bu sırada Abdurrahman Ömeri tarafindan hazırlanmış aile hukukuna dair bir Mecelle nüshasına rastladık. Mecelle'nin Abdurrahman Ömeri (ö. 1933) tarafindan yazım tarihi 1345 Hicri/1926 Miladi tarihtir. Tebliğimiz, Kazan bölgesindeki Mecelle çalışmalarının kısa hikâyesini, tespit ettiğimiz Mecelle nüshalarının ilim dünyasına tanıtılmasını ve içeriğinin kısaca değerlendirmesini konu edinecektir.

Anahtar Kelimeler: Mecelle-i Ahkâm-1 Şer'iyye, Ahmet Cevdet Paşa, Ceditçilik, Abdurrahman Ömeri, Musa Carullah, Şehabeddin Mercani, Aile Hukuku, Aile Hukuku Kararnamesi

\section{Abdurrahman ÖMerí ANd His Mecelle AtTempt on the FAMily LAW}

ABSTRACT: The famous work named Majallah al-Ahkam al-Adliyyah,which was prepared under the head of Ahmed Cevdet Pasha (d. 1895), had a significant impact on the Jadidism in the Kazan region. Majallah was also taught as a textbook in some madrasas in the area. The religious structure in the Kazan region was not hierarchical.

\footnotetext{
* Prof. Dr., Ankara Üniversitesi İlahiyat Fakültesi, ibrahimmaras@gmail.com, ORCID 00000002-1104-3802
}

(Yazının Geliş Tarihi/Received Date: 04.10.2021, Yazının Kabul Tarihi/Acceptance Date: 01.12.2021) 
U॰ İBRahim MARAS

In Tsarist Russia, Muslims were trying to solve their own problems such as inheritance, marriage and divorce. Imams in every neighborhood in the region were also performing the duty of Qadi. This situation caused serious differences in the religious regulations given. Therefore, a handbook consisting of codified provisions like the Ottoman Majallah was a basic need. Taking this into account, the Muslims of İdel-Ural argued that a new Majallah should be written in the field of family law. As the basic need of the Muslims of the Idel-Ural region was in the field of family law. However, there was no family law department in the Majallah, which was prepared under the chairmanship of Ahmed Cevdet Pasha.

In the meeting of the The Nadwat al- 'Ulamā in 1917, an advisory council was formed in the mufti in Ufa in line with the preparation of a Majallah under the chairmanship of the mufti of the time, Âlimcan al-Barūdī. However, due to the conditions of the period, these serious steps remained also inconclusive. Until now, it was not known whether or not a Majallah was prepared within the Ministry of Religion in Ufa. The classification and catalog of the manuscripts of the famous scholar Abdurrahman Umari was done by us. Meanwhile, we encountered a copy of Majallah on family law prepared by Abdurrahman Umari. The date of writing of Majallah by Abdurrahman Umari (d. 1933) is $1345 \mathrm{Hijri} / 1926$ c.e. Our paper will focus on the short story of the Majallah studies in the Kazan region, the introduction of the Majallah copies which we have acquainted to the scientific world, and a brief evaluation of their content.

Keywords: Majallah al-Ahkam al-Adliyyah, Ahmed Cevdet Pasha, Jadidism, Abdurrahman Umari, Musa Bigiev, Shihab al-Din al-Marjani, Family Law, Family Law Regulations

\section{İslam Hukuku ve İçtihat}

İslam hukukunda içtihat kapısı Hicrî IV. asırdan itibaren kapandı mı, kapatıldı mı (sed ve insidâd) tartışmaları hâlâ tazeliğini koruyan bir tartışmadır. Her ne kadar hukuk, hayat ile beraber devam eden olmazsa olmaz bir gereklilik ise ve içtihadın olmaması imkansız ise de maalesef, özellikle hicrî 100 ile 350 yılları arasındaki büyük müçtehitler döneminden başlayarak her geçen gün taklit ağırlık kazanmış ve yapılan içtihatlar, büyük müçtehitler dönemi içtihatlarına kıyasla çözümlenmiştir. Aslında bu süreç içerisinde hiç özgün içtihadın yapılmadığını söylemek zor olsa da, özellikle son 3-4 asırdır hayatın, hukukun çok önünde seyrettiği ve yeni usûl çalışmalarına ihtiyaç duyulduğu bilinen bir gerçektir. Burada üzerinde durulması gereken esas sorun, meşhur Mecelle yorumcusu Ali Haydar Efendi'nin dediği tarzda "belirli bir süre sonra müçtehitlik vasfina haiz bir insan gelmediği için kapanmıştır" gibisinden bir savunmayla geçiştirip İslam hukukunu ilk dönemden uzaklaştıkça hep ilk döneme ve aşılmaz görülen müçtehitlere bağlı kılan bir anlayışın hâkim olmasıdır. Hâlbuki böylesi bir anlayış, İslam'ın ve hukukun evrenselliğinin, kuşatıcılığının, hayatta karşılaşılan olayların sonsuz; hükümlerin ise sonlu olduğunun farkına varmamaktan kaynaklanmaktadır. Diğer yandan bu anlayış, nassı sadece fikıh perspektifinden okuyup nassın felsefi, kelâmî, sosyolojik, psikolojik ve tasavvufi yönünü görmezlikten gelmeyi öne çıkarmaktadır. Hatta bir diğer açıdan da Kur'an metnini sadece "Arapça" bir metin olarak değerlendirme ve bunu da tüm zamanlara hâkim kılma sonucunu ortaya çıkarmaktadır. Hâlbuki nassın lafzî 
tabiatının Hanefi anlayışa hâkim olan ancak zamanla unutulan, yaratılmış bir yöne sahip olduğunun çok iyi değerlendirilmesi, ilk müçtehitlerin başarısının altındaki faktörlerin iyi ortaya konulması gereklidir. Bu noktada meşhur Hanefî âlimlerden Kâsânî'nin Ebu Hanife'nin Arapça' dan farklı dillerde de mazeretsiz olarak ibadet edilmesi yönündeki içtihadının temelini açıklarken söyledikleri manidardır.

Kâsânî'ye göre, Ebu Hanife'nin başka dillerde de ibadetin câiz olduğuna fetvayı vermesinin altında yatan temel fikir, onun Kur'an'ın lafzı değil içeriği yönünden Kur'an olmasıdır. Bu sebeple aynı içerik başka lafızlarla da caiz olmaktadır (Okur, 2002/1-2:86). İslam dünyasında, her zaman olduğu gibi, bundan sonra da tıpkı ilk dönem müçtehitler benzeri, yeni müçtehitlerin pekâlâ da çıkabileceği anlayışını öne çıkarmak ve bunun önemini yeni nesillere iyice kavratmak en önemli görevlerimizden olmalıdır.

Tarihte, belki de Hanefî mezhebinin Mecelle'yi hazırlayanların da üzerinde durduğu gibi; ihtilaf açısından zenginliğinin, geniş yayılım alanının, çok çeşitli dallara ayrılmasının, sistematik olmamasının ve öğrenilmesinin çok zor oluşunun temel sebebini; onun, hukuka, daha geniş, aklî, gerçekçi, devrin ihtiyaçlarını gözeten, kitap ve sünnetin zahiriyle beraber ruhunu dikkate alan, evrensel ahlâkî değerleri gözeten, hem bireyi hem de toplumu bir arada değerlendirebilen idealist bir perspektiften bakma çabasında görmek gereklidir (Ansay, 1954:39-40). Kanaatimizce Hanefi geleneğin bahsettiğimiz bu zenginliğinin ve açılım kabiliyetinin sonradan bozulmuş olmasına rağmen, kökeninde Kur'an metninin mânâ olarak Allah'a ait, lafız olarak ise "yaratılmış" görülmesinin büyük payı vardır. Nitekim çağdaş hukukçulardan Karaman da içtihatla ilgili eserinde, sahabe dönemindeki içtihat anlayışıyla ilgili olarak belirli usûl ve kaidelere bağlı olmama (usulsüzlük anlamında değil), metnin lafzıyla beraber ruhuna inme, aklî yorum, zaman ve mekân farklılıkları ve devrin ihtiyaçları gibi özellikleri sıralamaktadır (Karaman, 1975: 51-80). Karaman'in burada sıraladıkları hukukun ruhunu ifade etmektedir. Eğer hukukun bu ruhuna riayet edilmezse İslam hukuku, belirli dönemlere, kalıplara mahkum edilecek ve güncel birçok problemimizi çözmede İslam'ın ve hukukun ana hedefi olan "adaleti yerine getirme" ilkesini zedeleyecektir. Günümüzde pek çok İslam ülkesinde buna açıklıkla şahit olunmakta ve hatta temel hak ve özgürlükler bile, bu bahanelerle ihlâl edilebilmektedir.

\section{Osmanlı'da Mecelle ve İdil Ural'da Yansımaları}

Osmanlı Devleti, XIX. asırda yukarıda bahsetmeye çalıştığımız sıkıntıların farkına vararak Ahmed Cevdet Paşa'nın başkanlığındaki bir heyete Mecelle'yi hazırlattırmıştır. Hazırlanan Mecelle-i Ahkâmı Adliyye adlı meşhur eser, hiç şüphe yoktur ki İslam dünyasının son iki yüzyılına damga vurmuş ve bazı hukukçular tarafindan İslam hukuk tarihinin önemli dönüm noktalarından birisi kabul edilmiştir. Mecelle; aile, miras, vasiyet ve vakıf hükümlerini barındırmayan, borçlar, eşya ve muhakeme usulüne dair maddeleri içeren, miladi 1869-1876 (1286-1293 hicri) tarihleri arasında çıkarılmış, bir madde fikıh tarifi, 99 madde 
U・ İ̈rahim Maraș

külli kaideler ve 1851 maddeden oluşan bir çeşit Osmanlı dönemi medeni kanunudur (Ansay, 1950:50) ${ }^{1}$. Hazırlanan bu mühim eser, Türk dünyası ve Balkanlarda, Filistin'de, Lübnan'da hukuki muamelelerde kullanılmış ve medreselerde okutulmuştur.

Mecelle'nin etki alanı içerisindeki en önemli bölge, hiç şüphesiz İdil-Ural coğrafyası olmuştur. Bu coğrafya, 1552'den bu yana bağımsız olmamakla birlikte, XIX. asrın başlarından XX. asrın ilk çeyreğine kadar İslam dünyasındaki en önemli tecdit hareketlerinden birinin merkezi olmuştur. Ceditçilik hareketi olarak bilinen ve dini düşüncede, eğitimde ve millî kimlik alanında uyanışı hedef alan söz konusu fikrî yapılanma; Abdünnasır Kursavî, Şihabüddin Mercânî, Rızaeddin Fahreddin, Musa Carullah, Abdurrahman Ömerî, Ziya Kemâlî ve Abdullah Bûbi gibi çok sayıda ceditçi din âliminin yetişmesine zemin hazırlamıştır. Bu ceditçiler üzerinde, başta Hint yenilikçi Şah Veliyullah olmak üzere, Osmanlı düşünürlerinin ve hepsinden önemlisi Mecelle'nin önemli etkisi olmuştur. Mecelle, bölgedeki bazı medreselerde ders kitabı olarak da okutulmuştur (Feyizhanoğlu, 1893:19-20; Muzafferov, 1912/15:74).

Kazan Türklerinde Mecelle hazırlama isteğinin tam olarak ne zaman başladığı bilinmese de, 1900'lerin başında gündeme geldiği bilinmektedir. İdil-Ural bölgesinde yeni bir Mecelle hazırlanmasına yönelik çabanın altında yatan sebep, gerçekte Osmanlı'daki Mecelle'ye bir alternatif çıkarmak değil, o Mecelle'de bulunmayan ve bölgede esas ihtiyaç duyulan aile ve miras hukuku kısmının eklenmesidir. Bunun dişında bölgedeki ceditçi âlimler farklı mezheplerin içtihatlarından da yararlanabilecek bir Mecelle'den yanaydı. Çünkü Kazan bölgesindeki dinî teşkilatlanma Osmanlı ve Türkistan gibi hiyerarşik bir yapı arz etmiyordu. Ufa'daki Diniye Nezaretinin Müslüman ulema üzerindeki etkisi çok güçlü değildi. Çarlık Rusya'sında Müslümanlar miras, evlenme ve boşanma gibi meselelerini kendileri çözmeye uğraşıyorlardı. Bölgede her mahalledeki imamlar, aynı zamanda kadılık görevini icra ediyorlar; evlenme, boşanma ve miras gibi hususları çözümlemeye çalışıyorlardı. Söz konusu toplumsal meseleleri karara bağlayacak ayrıca bir müftü yoktu. Her şey mahallinde çözümlenmekteydi. Elbette imamet ve kadılık görevini üstlenen bu kişiler Diniye Nezareti tarafından kendisine yetki (ukaz) verilen kişilerdi, oraya ve Çarlık Rusyası kanunlarına karşı sorumluydular. Bölgede, her mahalleye iyi derecede yetişmiş ve kadılık görevini icra edebilecek imam bulabilmek neredeyse imkânsız olduğundan hukuki muamelelerde ciddi sıkıntılar baş göstermiştir. Buna bir de kitap yetersizliği, Hanefi fikhının işaret ettiğimiz zorluğu ve karışıklığını ve en önemlisi imamların/kadıların bölgedeki meseleleri "zamanın hayatına tatbiki”nde yaşadığı problemleri ilave ettiğimizde hukuki işlemlerdeki birliğin sağlanması iyice

${ }^{1}$ Bu konuda daha detaylı bilgi için bkz. Osman Öztürk, Osmanlı Hukuk Tarihinde Mecelle, İst. 1973. 
zorlaşmıştır. (Fahreddin, 1903:2-7)². Bu yüzden bölgede Osmanlı tarzı kodifike edilmiş hükümlerden oluşan bir el kitabı niteliğinde Mecelle'ye ihtiyaç vardı.

İdil-Ural bölgesinde Mecelle ile ilgili ilk olarak ilk çalışmayı Musa Carullah yapmıştır. Onun, Kavaid-i Fıkhiyye ismindeki eserini bu amaçla yazdı̆̆ 1 bilinmektedir. Meşhur ceditçi düşünür Rızaeddin Fahreddin'in teşvikiyle Musa Carullah, Mecelle tarzında, Kavâid-i Fikhıyye adlı eserini yazmıştır. Bu kitapta yer alan 201 maddenin 100 tanesi Cevdet Paşa'nın Mecelle'sinden alınmıştır. Ancak, bir giriş mahiyetinde yazılan bu eser, yazarın kendisinin de ifade ettiği gibi, hem biraz acele ile kaleme alındığından hem dönemin kadimci-ceditçi kavgasındaki karşılıklı fikri sataşmalar sebebiyle hem de bir komisyon tarafından hazırlanmamasından dolayı, bölge Müslümanlarının hayatında çok fazla etkili olamamış ve kabul görmemiştir. Musa Carullah, bu eserinde maslahatı ve zamanın gereklerini ön planda tutmuş ve daha baştan fikhın tarifini "bir toplumun üyesi olmak sıfatıyla insanın öz hukuklarını, öz vazifelerini tamamıla bilmektir" (Carullah, trsz.:1) şeklinde yapmıştır. Ona göre usûl-i fikıh kitaplarında 14 tane aslî delil zikredilmektedir: Kitap, sünnet, icma, kıyas, maslahat, istishab, beraat-i asliyye, istihsan, sedd-i zerayi', avâid (adetler), istikra, burhan-1 indirac, burhan-1 telazüm, burhan-1 te'ânüd. Bu maddeleri sıralarken maslahatla ilgili kısımda söylediği şu sözler onun fikıh usulüne bakışını ortaya koymaktadır: "Semavi yahut medeni kanunların ehemmiyeti, yalnız insanların maslahatlarına muvafakatlarıyladır." (Carullah, trsz.:3). Bu bakış, görüldüğü gibi toplumu ve yararını ele alan bir bakış açısıdır. Bununla birlikte Carullah'ın Kavaid-i Fıkhıye'si genel kaideler şeklidedir ve toplumun daha temel bir ihtiyacı olan aile ve mirasla ilgili konuları çözümlemede yetersizdir.

Musa Carullah'tan bağımsız olarak İdil-Ural bölgesindeki bir kısım âlimler, hiçbir mezheple kayıtlanmaksızın ve diğer mezheplerin içtihatlarından da faydalanılarak yeni bir Mecelle yazılması gerektiğini ve bunu da bir komisyonun yapmasının lüzumunu hep savunagelmişlerdir. Bölgede yeni bir Mecelle'nin hazırlanmasına ihtiyaç duyulmasının sebebi, Osmanlı Devleti'ndeki ile benzerlik arz etse de yukarıda belirttiğimiz sebepler dışında çok önemli diğer bir faktör de bunda büyük etkendir. Bölgede 1800'lerde başlayıp 1880'lere doğru iyice güçlenen dinî ve millî uyanıș hareketi hemen her konuda yeni bir düzenleme ihtiyacı doğurmuştur. Ancak dönemin şartları ve ceditçi-kadimci tartışmaları bu konuda mesafe alınmasına izin vermemiștir. Bu konudaki ilk ciddi adım 18-27 Temmuz 1917'de atılmıştır. Kazan'da İdil Ural'dan 270 kadar seçkin kişinin toplandığı 1917 Ulema Nedvesinde Mecelle konusu gündeme getirilmiş ve "Kur'an ve hadise dayanan bütün mezheplerin zamana ve mahalli adetlere muvafık içtihatlarından" faydalanılarak "tigiz", yani her imamın aynı șekilde ve kolaylıkla anlayabileceği tarzda ve el kitabı mahiyetinde bir Mecelle hazırlanması

${ }^{2}$ Rızaeddin b. Fahreddin, hem Mütalaa adlı eserinde hem de başka eserlerinde bölgedeki dini durum ve hüküm vermelerdeki problemleri detaylıca anlatmaktadır. Genel olarak dini durum ve meseleler için bkz. Rızaeddin b. Fahreddin, Menasıb-1 Diniyye, Orenburg trsz. Nikah ile ilgili problemler için bkz. Mütalaa, Petersburg 1902. 
Uค İ̈RAhim Maraș

gerekli görülmüştür. Tabii ki hazırlanacak Mecelle, imamların/kadıların yetki sınırları ölçüsünde olacağından öncelikle nikâh, talak, nafaka ve feraiz (miras) meselelerini kapsamalıdır. 1917'de toplanan komisyonun diğer mezheplerin içtihatlarının kullanılmasını istemesi önemlidir. Bu durum temel bir ihtiyaçtan kaynaklanmaktadır. Komisyon, buna dair bir örnek de vermekte; özellikle mefkudun hükmü ve nafakadan aciz kişilerin eşleri hakkındaki Hanefi fikhında "taassup" göstermenin kadınların haklarını bir çeşit ihlâl manasına geleceğini söylemektedir. Bu açıdan alınan kararlarda, yazılacak Mecelle'de kitap ve sünnet esas tutulmakla birlikte Hanefi mezhebinin me'haz alınacağ 1 , gerektiğinde başka mezheplere, mezhepte olmayan veya mezhepte olup da mevcut hayata uymayan meselelerde ise şeriat usûlünden istinbat ve istihraç edilmesi ve nihayet örf ve adetlerin esas alınması (Şeref, 1917: 40-42) metodu benimsenmiştir. Böylece hukuki muamelelerde belirli oranlarda yerellik vurgusu yapılmıştır. Ulema heyeti, ayrıca söz konusu bu kural ve metotların az bir farkla, aynı yılda yaklaşık bir ay önce 15-22 Haziran'da Ufa'da Mahkeme-i Şer'iyye (Diniye Nezareti) bünyesinde toplanmış olan Ulema Kiñeş Meclisi (Danışma Kurulu) toplantısında belirlenen Mecelle-i Ahkâm-ı Şer'iyye hazırlama ile ilgili kurallar olduğunu ifade etmektedir.

1917 Ulema Heyeti'nin toplantısında hazırlanacak Mecelle'ye dair bir komisyon belirlenmiş ve mümkün olduğunca geniş tutulması için Türkistan, Kafkas ve Kırım ulemasının da komisyona üye katkısında bulunması istenmiştir. 1917 Ulema Nedvesi, Mecelle komisyon üyelerinin seçimini yapmış ve azami üç yıl içerisinde bitirilmesini istemiştir. Nedve'de 11 kişilik komisyonun üyeleri, yapılan seçim sonucu şu şekilde belirlenmiştir: Dönemin ilk seçilen Müftüsü (Rusya Müslümanları Diniye Nezareti Başkanı) Alimcan Barûdî, Müftü Yardımcısı Kadı Rızaeddin b. Fahreddin, Müftü Yardımcısı Kadı Hasan Ata Abeşî, Muhammed Necip Tünteri, Ziyaeddin Kemâlî, Musa Carullah, Muhammed Murad Mekkî, Müftü Yardımcısı Kadı Salihcan Urmânî, Hüccetülhakim Mahmud, Muhammed Sabir Hasenî ve Sadık İmankulu. Heyete seçilenlere, lüzum görülen kişilerin de heyete alınması konusunda Nedve tarafından tam yetki verilmiştir. Mecelle, bitirildikten sonra Diniye Nezaretindeki bir ulema heyeti tarafindan incelenip onaylanacak ve sonra bütün imamlara uygulanmak üzere gönderilecektir. Ulema Nedvesi, bunlar dışında, oluşturulan matbuat şubesi ve onun reisi olan, aynı zamanda Nedvenin Başkanlık Heyetinde de yer alan Abdurrahman Ömeri'nin (ö. 1933) teklifleriyle, Mecelle komisyonundan bir de aynı mecmuanın başvurdukları delil ve kaynaklarını gösteren şerhli bir ikinci Mecelle istemiştir (Şeref, 1917:41-43). Nedvede oluşturulan bu komisyonun, toplanmasının hemen akabinde gerçekleşen Bolşevik İhtilali ve onun getirdiği sıkıntılar, iç savaş, 1920'li yıllardaki korkunç açlık yılları yüzünden, görevini yerine getirmediğini bilmekteyiz. 1921'de Müftü Alimcan Barûdî'nin ölümü üzerine boşalan müftülük makamına Mecelle hazırlanması konusunda yüzyılın başından beri çok gayret eden Rızaeddin Fahreddin'in seçilmesi yeni bir çabayı daha gündeme getirmiştir. Müftülük bünyesinde oluşturulan Ulema Şurasının Temmuz 1924'teki toplantısında Mecelle konusu yine görüşülmüş ve Abdurrahman Ömerî hariç, isimlerini tespit edemediğimiz 
kişilere paylaştırılarak bu kişilerden ilgili bölümleri yazmaları istenmiştir. Aile ile ilgili kısmın yazımı Abdurrahman Ömerî’ ye verilmiştir. Abdurrahman Ömerî, 1926 yılında 551 maddelik Mecelle-i Ahkâmı Şer'iyye'nin Ailege Aid Kısmı adlı çalışmasını tamamlayarak kendisinin de üye olduğu Ulema Şurasına takdim etmiştir. Ulema Şurası bu eseri onaylayıp basılma kararı çıkarsa da bugüne kadar basılmamıştır (Rahimov, 2003:28-29).

\section{Abdurrahman Ömerî’nin (ö. 1933) Mecelle-i Ahkâm-ı Şeriyye'si}

Kazan'da yaptığımız ilmî çalışmalar sırasında Şehabeddin Mercani'nin öğrencisi Abdurrahman Ömeri ${ }^{3}$ tarafindan hazırlanmış, aile hukukuna dair 551 maddelik Mecelle-i Ahkâm-ı Şeriyye'nin Ailege Ait Kısmı isimli bir yazma nüsha tarafımızdan bulunmuştur. Elimizdeki bu Mecelle'yi değerlendirirken Osmanlı Devleti'nde hazırlanan Mecelle'de aile bölümü yer almadığından, yazılış tarzı ve ruhu bakımından Osmanlı'daki Mecelle ile içerik bakımından ise, "1917 Hukuk1 Aile Kararnamesi" ile karşılaştırılması gerekmektedir. Biz burada söz konusu yazmayı kısaca değerlendireceğiz. Konuya dair hâlen yapmakta olduğumuz daha geniş bir çalışmayı ileride bu yazmanın neşri ile birlikte yayınlamayı düşünüyoruz.

Abdurrahman Ömerî’nin hazırladığı Mecelle-i Ahkâm-ı Şer'iyye'sinin müellif nüshası ve Ulema Şurasının onayladığı nüsha maalesef bugüne kadar bulunamamıştır. 2005 yılında Rusya Federasyonu'na bağlı Tataristan Özerk Cumhuriyeti başkenti Kazan'daki çalışmalarım sırasında, meşhur âlim Şihabüddin Mercani'nin talebesi olan Abdurrahman Ömeri'nin arşivi Moskova'da yaşayan torunları tarafından Tataristan Milli Arşivine bağışlanmıştı. Söz konusu arşivin tasnif ve kataloğunun yapılması da tarafımdan istenmişti. $\mathrm{Bu}$ tasnif çalışmaları sırasında Abdurrahman Ömeri'ye ait pek çok el yazma belge ve eser arasında beş adet de Mecelle nüshasına rastlandı. Bunların hiçbirisinin müellif nüshası olmadığı tespit edilmiş olmakla beraber, bunlardan ikisinin tam nüsha (551 madde), üçünün de eksik istinsah edilmiş olduğu tespit edildi. İki tam nüshadan birisi doğrudan asıl nüshadan Abdülhalim Basîrî Efendi tarafından, yazımından çok kısa bir süre sonra, 1926-28 yıllarında, istinsah edilmiştir ve bu nüshada, Abdülhamit Ömeri’nin de dediği gibi, Abdurrahman Ömeri'nin kendi el yazısıyla bazı düzeltmeleri vardır. Yani bizzat müellif tarafından kısmen veya tamamen gözden geçirilmiş bir nüshadır. Diğeri ise Abdurrahman Ömerî’nin oğlu Abdülhamit Ömeri tarafindan bu nüsha ve diğer üç nüshadan hareketle, 1977'de istinsah edilmiştir. Abdülhamit Ömeri, bu istinsahı, muhtemelen, 1970'li yıllarda babasının sağa sola dağılan arşivini yeniden toparlamaya çalıştığı sırada yapmış;

\footnotetext{
3 Abdurrahman Ömerî, Astarhan bölgesi Nogay Türklerindendir. 1867'de Astarhan'da doğmuştur. Kazanlı büyük Türk âlimi Şehabeddin Mercânî’nin öğrencisi olmuştur (18811889). Bölgedeki usûl-i cedit hareketine ve siyasi toplantılara iştirak etmiş ve kendisi de usûl-i cedit mektep ve medresesi açmıştır. Ayrıca İdil gazetesini çıkarmıştır (1907-1914). Daha detaylı bilgi için bkz. Süleyman Rahimov, Gabdrahman Gömeri, Kazan 2003: Ruhiyat Neş.
} 
U・ İ̈rahim Maraș

söz konusu istinsahı ise 1977 'de bitirmiştir. Abdülhamit Ömeri, bu dönemde bir de babasının biyografisini kaleme almıştır. Bu biyografi, Kazan'da basılmıştır (Rahimov, 2003:14-95).

Elimizde bulunan eksik nüshalardan birisi, 354 madde içermektedir ve Yahya Molla Hediyetullahoğlu tarafından istinsah edilmiştir. İkincisi 405 madde içermektedir Abdülkari (Abdikari) Molla Küşmuhammedoğlu tarafından istinsah edilmiştir. 346 maddelik nüsha da Hatip Mollaoğlu Abdülhamit eliyle yazılmıştır. $\mathrm{Bu}$ nüshaların tamamının fotoğrafları şahsi arşivimizde bulunmaktadır. Henüz Tataristan Milli Arşivinde kayıtlara girmediği için burada arşiv numaraları verilmemiştir. $\mathrm{Biz}$ bu tebliğde bütün nüshaları göz önünde bulundurmakla birlikte, iki tam nüshayı esas alacağız.

Elimizde bulunan Mecelle'nin yazımının bitiş tarihi hicri 1345, miladi 1926'dır. Abdurrahman Ömerî, söz konusu Mecelle'nin hazırlanış sebebine dair giriş kısmına yazdığı yazıda; XX. asır başlarında İdil Ural bölgesindeki Müslüman Türklerin toplumsal ve kültürel hayatlarındaki gelişmeler çerçevesinde karşılaştıkları dinî ve dünyevi meseleleri çözebilecek bir fıkıh anlayışına ihtiyaç duyduklarını ve bu meyanda şer'î hükümleri ortaya koyabilecek bir mecmua yazma isteklerinden bahsetmektedir. Burada onun üzerinde durduğu önemli iki noktadan birisi, söz konusu mecmuanın, hüküm birliği sağlanması için, bölgenin her tarafina dağıtılması, diğeri ise, "avam imamların" bile anlayabilecekleri ve onlara rehber olabilecek açık bir "Türk̂̂" dilde ve "kolaylık”ta olmasıdır. Ömerî, çok kısa bir şekilde Mecelle'nin 1917'den başlayan hikâyesine de yer vermekte ve 1923'te Ufa'da toplanan Umum Müslümanlar Nedvesinde alınan bir kararla Diniye Nezareti bünyesinde oluşturulan Ulema Şurasına atıfta bulunmaktadır. Bu şuranın esas görevinin çeşitli bölgelerden Diniye Nezaretine yöneltilen sorulara fetva vermek ve zamana uygun dinî kitaplar yazmak olduğunu ifade eden Ömerî, söz konusu şuranın bir toplantısında (Abdülhamit Ömeri 1924'te gerçekleştiğini yazmaktadır) Mecelle-i Ahkam-l Şeriyye'yi yazma görevinin birkaç bölüm halinde paylaştırıldığını (burada kişi ve bölüm isimleri vermemektedir) ve kendisine de aileye dair kısmın yüklendiğini belirtmektedir. Yapılan toplantıda, yazımda Hanefi mezhebinin esas alınmasının ancak çok gerektiğinde başka mezheplere başvurulmasının kararlaştıııldığının da altını çizmektedir. Bu ifadelerden de anlaşılacağı üzere bölgedeki ilk Mecelle tartışmalarından zihniyet olarak geriye doğru gidilmiş ve Mecelle, Osmanlı'daki ile aynı ruhta hazırlanmıştır. Ömerî, kendisinin ilk olarak nikah, talak ve nafakalara dair 365 madde yazdığını ve bunu 1926'da toplanan Umum Müslümanlar Nedvesinde Ulema Şurasına sunduğunu, bunun özel bir komisyon tarafından tashih ve tenkit edildikten sonra onaylanıp basılmasına karar verildiğini söylemektedir. Ömerî, aynı yıl basım işi için gittiği Moskova'da hırsızlar tarafından çantasının çalındığını ve yazdığı asıl nüsha ile istinsah edilmiş bir nüshanın böylece kaybolduğunu büyük bir üzüntü ile anlatmaktadır. Memleketi Astrahan'a döndükten sonra çevresinin 1srarılla daha mükemmel bir şekilde yeniden kaleme aldığını vurgulayan Ömerî, bu kez ferâiz bahsini de 
eklemiş ve 550 maddeye çıkarmıştır. Oğlunun da belirttiği üzere, kendisinin, istinsah edilen bir nüshaya düştüğü notlara yeni bir madde daha ilave etmesiyle aile kısmı toplam 551 madde olarak tekemmül etmiştir (Ömerî, 1977:7(a)-8(a) ${ }^{4}$.

Abdurrahman Ömerî’nin bu ikinci kez yazımı kısa bir süre içerisinde, 1926 yılı sonları ile 1927 yılı başlarında, bitirdiği girişin sonuna yazdığı hicrî 1345 tarihinden görülmektedir.

Abdurrahman Ömerî, hazırladığı Mecelle'de kul-kenizek (köle ve cariye) meselelerine yer vermediğini, artık İdil-Ural'da bunların çoktandır bulunmadığını ve bunlarla uğraşmanın da boşa vakit geçirmek olduğunu zikretmektedir. Ömerî, alınan kararlar doğrultusunda Hanefi mezhebini esas almış ve zaruri durumlarda diğer mezheplerden faydalanmıştır. Bu konuda faydalandığı kitapların isimlerini de yazmıştır. Buna göre elimizdeki Mecelle'de; Şafii mezhebinde, İmam Şafii'nin Kitabu'l- Umm ve Kitabu Şerhi'l-Muhallâ Alâ Minhâci'n-Nevevi, Maliki mezhebinde İmam Malik'in el-Müdevvenetü 'l-Kübrâ ve İbn Rüşd'ün Bidâyetü'lMüctehid ve Nihayetü'l-Muktesid, Hanbeli mezhebinde, Abdulkadir bin Ömer EtTağlibi eş-Şeybani'nin Neylü'l-Meârib Şerhu Delili't-Talib ve meşhur Hanbeli fıkıhçı Şeyh Mansur b. Yunus el-Behuti'nin (ö. 1641) er-Ravzü'l-Mürbi bi-Şerhi Zâdi'l-Müstanki' kitapları ve bunların haşiyeleri (Ömerî, 1977:8(b) kaynak olarak kullanılmıştır.

Abdurrahman Ömerî’nin hazırlamış olduğu aile ve miras hukukuna dair bu Mecelle, hazırlanışta uyulan esaslar bakımından Osmanlı Mecelle'sine benzese de esas olarak 1917 Osmanlı Aile Hukuku Kararnamesi ${ }^{5}$ ile mukayese edilmelidir. $\mathrm{Bu}$ mukayesede ilk göze çarpan husus elimizdeki Mecelle'de, Aile Hukuku Kararnamesi'nde bulunmayan miras hukukuna da yer verilmiş olmasıdır. $\mathrm{Bu}$ açıdan Ömerî’nin çalışması bazı önemli yenilikler ve tarifler barındırsa da Aile Hukuku Kararnamesi'nden ve dönemin ceditçi anlayışından zihniyet olarak uzaklaşan yönleri de bulunmaktadır. Meselâ Ömerî, İdil-Ural ve hatta Türkistan için yazdığı söylenebilecek çalışmasında evlilikteki denklik meselesini beş maddede ele almıştır: "Neseb ve nesil, Müslümanlık, dinlilik, hüner ve sanat". Ömerî, İdil-Ural ve Türkistan bölgesi için yazdığı bu maddelerde, garip bir şekilde, Arap halkındaki neseb ve nesil üzerinden denkliği, yani örfe dayalı kabileci anlayışı esas almaktadır. Arap olmayanlardaki denklikte ise Müslümanlıktaki durumunu ele almaktadır (Ömerî, 1977:20(a)-208(b). Hâlbuki, meseleyi sadece dinî, ahlâki ve statü denkliği ile alması gerekirdi. Nitekim Aile Hukuku Kararnamesi konuyu, "mal ve hırfette (hüner ve sanatta) denklik" olarak

${ }^{4}$ Abdurrahman Ömerî’nin Mecelle-i Ahkâmı Şer'iyye'nin Ailege Aid Kısmı adlı el yazmasının, Abdülhamit Ömerî istinsahında Bir deftere Arap harfleriyle Tatar lehçesinde yazılmıştır. Bu yüzden metindeki varak numaraları tarafımızdan verilmiştir. Ayrıca bu eser Tataristan Milli Arşivi'nde henüz yer almadığı için elimizdeki fotoğraf nüsha kullanılmış ve yer numarası verilmemiştir. Bundan sonraki atıflarda Abdülhamit Ömeri nüshası kullanılacaktır. Çünkü bu nüsha diğer dört nüshayı esas alarak istinsah edilmiştir.

5 Aile Hukuku Kararnamesi hakkında daha detaylı bilgi için bkz. Osmanlı Hukuk-ı Aile Kararnamesi, Haz. Orhan Çeker, Konya 2017. 
Uค İ̈Rahim Maraș

ele almıştır ${ }^{6}$. Neseb ve nesil üzerinden denklik ele alınacaksa aslında bu doğru olmayan bir yaklaşımdır, Ömerî'nin tıpkı Araplardakine benzer kuralları olan Kazaklardaki benzer meseleleri de gündeme getirmesi gerekirdi.

Abdurrahman Ömerî, Mecelle'sinin sonuna düştügü notta hile-i şer'iyye meselesine de girmekte ve bunun, Türkçe'de aldatmak değil hukuki çözüm anlamına geldiğini belirtmektedir. Böyle olmadığı hâlde hukuktaki uygulamalarla bunun aldatma anlamı haline getirildiğinden şikâyet etmektedir. Ömerî, haklı olarak hukukta hileye başvurulmasının, yani hukuki bir çözüm üretilmesindeki ana amacın ahlâki ve metafiziki olduğunu, yani Allah'a ibadetin, yakınlığın gözetilmesi ile iyilik ve erdem yönünün tercihi olduğunu beyan etmektedir (Ömerî, 1977:80(a)-81(b). Bu, esasında ferdin ve kamunun yararının gözetilmesi anlamına da gelmektedir. Ömerî’nin buradaki yaklaşımı oldukça önemli ve değerlidir.

Bir başka örnek şu şekildedir: İçki, afyon vb. aklı gideren şeyler etkisinde ortaya çıkan talak, Aile Hukuku Kararnamesi'nde "sarhoşun talakı muteber değildir" " şeklinde geçerken Ömerî; çerçeveyi biraz genişleterek afyon, esrar ve içki gibi aklı baştan alan şeylerde talakı muteber saymamakta ancak bir şerh düşerek bunu "aklı bulunmama" sebebine bağlamaktadır. Ayrıca bazı fakihlerin bu tür şeylerden men etmek için bu talakı muteber gördüklerini de zikretmektedir (Ömerî, 1977:27(b)-28(a).

Yine bir başka örnekte Aile Hukuku Kararnamesi'nde talaktan bahsedilirken "talakın ehli mükellef olan zevçtir" ${ }^{8}$ denilmekte, mahalli ise kadın olarak kabul edilmektedir. Ömerî ise talak için "akd-i nikah ile hasıl olan bağlanışı boşatmaktır" demekte ve er veya kadın tarafı demeden genel bir tarif yapmakta ve daha eşitlikçi bir tutum sergilemektedir. Ancak o da kadının, önceden kocasından aldığı izin dışında kendisini boşama hakkının olmadığını söylemekte ve klasik fikhi çizgiden vazgeçmemektedir (Ömerî, 1977:26(b)-27(a). Hatta Ömerî, "ben senden bezdim" sözünden bile bain talak gerçekleşeceğini ifade etmektedir.

Son bir örnek olarak, Aile Hukuku Kararnamesi, evlilik için asgari yaş haddi getirirken (erkeklerde 12, kızlarda 9 yaş buluğ çağı olarak belirlenmiştir) ${ }^{9}$ Ömerî, buluğ çağı yaşı ile ilgili olarak erkek için 18 , kız için 17 yaşını vermekte; kız veya erkeğin buluğa erdiklerini iddia etmeleri durumunda ise buluğ alt sınırının erkek için 12, kız için 9 olduğunu ifade etmektedir. Ancak evlilik konusuna geldiğinde

\footnotetext{
${ }^{6}$ Aile Hukuku Kararnamesi'nde bu konu 45. maddede şu şekilde ele alınmıştır: “Mal ve hırfet gibi hususlarda erkeğin kadına küfv olması nikâhın lüzûmunda şarttır. Malda kafâet zevcin mehr-i muacceli îtâya ve zevcenin nafakasını tedârike muktedir olmasıdır. Hırfetde kefâet zevcin sülûk ettiği ticaret veya hizmetin şerefce zevce velîlerinin ticaret veya hizmetleriyle mütekarib olmasıdır".

${ }^{7}$ Aile Hukuku Kararnamesi, 104. madde.

${ }^{8}$ Aile Hukuku Kararnamesi, 102. madde.

${ }^{9}$ Bkz. Aile Hukuku Kararnamesi, 4-8. maddeler.
} 
ise herhangi bir sınırlama getirmeden küçük kız ve erkek çocukların evlendirilmesinden bahsetmekte; bu evlilikte velilerinin hakkı olduğunu, eğer veli babası ve dedesi ise çocuk büyüdüğünde bu nikâhı feshedemeyeceğini, diğer velilerinin evlendirmesi durumunda büyüdügünde dilerse nikâhı feshetme yetkisinin, kadı hükmü şartıyla, mümkün olduğunu belirtmektedir. Her ne kadar ilgili maddenin altına düştüğü dipnotta dönemin Rusya kanunlarının erkeklerde 18 , kızlarda 16 yaşı alt sınır olarak şart kıldığını söyleyerek bu tür evliliklerden sakınmak gerektiğini söylese (Ömerî, 1977:22(a)-22(b) de Ömerî’nin maddeyi yazış tarzı anlaşılmazdır. Hâlbuki bölgede 1917 'den beri yapılan toplantılarda bu meselenin istismarından bahsedilmişti. Ömerî, anlaşılmaz bir şekilde konuyu Mecelle'sine klasik gelenektekini tekrar ederek almış ve bölgedeki problemin çözümüne bir katkıda bulunmamıştır.

Yukarıda belirtildiği üzere Ömer̂̂’nin hazırlamış olduğu Mecelle, Osmanlı Mecelle'sinde olmayan aile kısmını içermesi, Aile Hukuku Kararnamesi'nde bulunmayan miras hükümlerini barındırması, telfikçi çizgisi ve en önemlisi Osmanlı sahası dışında bağımsız bir Mecelle çalışması olması gibi yönlerden bir özgünlüğe sahiptir. Bu kısa yazının sınırlarını aşan başka özgünlüklerinin bulunduğu da açıktır. Ancak bununla birlikte çalışma, yukarıda da zikrettiğimiz gibi, bazı yönlerden, İdil-Ural'da 1900'lü yılların başından beri yapılan Mecelle tartışmalarındaki istenen zihnî çizgiye ulaşamamış ve geleneğin baskısının önüne geçememiştir. Elbette bunda, dönemin Bolşevik Rusya'sında yaşayan Müslümanların sıkıntılı durumlarının da etkisi bulunmaktadır. Ebul'ula Mardin'in Osmanlı Mecelle'si ile ilgili şu ifadelerini, elimizdeki Mecelle'ye ve Aile Hukuku Kararnamesi'ne de teşmil edecek olursak bütün iyi yönlerine rağmen, bahsi geçen bu çalışmaların, hukuk felsefesi açısından, yeterince geniş bir düşünceden hareketle yazılmadığı anlaşılmaktadır:

“Mademki Fransa Medenî Kanunu'nu bile tercüme ettirip nizamiye mahkemelerinde olsun tatbik ettirebilmek cesaretini gösteren bir heyet-i vükelâ mevcuttu, mademki Camiü'l-Ezher'in hüküm sürdüğü Mısırda bugün bile büyük çapta ıslahata tahammül göstermeyen bir taassuba karşı Fransa Medenî Kanunu Arapça'ya tercüme edilerek tatbik mevkiine konmuştu, mademki Âli Paşa Girit'ten gönderdiği meşhur lâyihasında bu lüzumu her türlü tehlikeyi, mesuliyeti gözönünde tutarak, bir teklif mahiyetinde yazabilmiş ve hatta devletçe Fransa Medenî Kanunu'nun tercüme ettirilmek üzere Arapça nüshası sadr-1 esbak Sait Paşa merhuma verilerek fiiliyata geçirilmişti. Şu halde yalnız Hanefi mezhebine ait hükümlerle iktifa etmeyip asrın ihtiyaçlarına cevap verecek diğer mezheplerdeki hükümlerden istiane [destek istemek] ve hatta icap ederse garp hukukunun işlenmiş ve mütekâmil hükümlerinden istifade edip öz, millî bir Medenî Kanun vücuda getirmek düşünülen ve terviç [itibar] edilen şekilden şüphesiz ki ehvendi" (Mardin, 2011/13 (3):931).

Ebul'ula Mardin'in de satırlarından anlaşıldığı üzere hukuki meselelerde esas husus, ferdi ve toplumsal hakların adalet çerçevesinde korunmasıdır. Bunun için de daha geniş bir perspektiften bakmak ve çözüm üretmek gereklidir. 
Uค• İBRAhIM MARAȘ

Abdurrahman Ömerî’nin oldukça değerli olan bu Mecelle çalışması, birçok yenilikçi yanına rağmen bu geniş perspektifi yeterince yakalayamamıştır.

\section{Kaynakça}

Ansay, Sabri Şakir (1954). Hukuk Tarihinde İslam Hukuku (2. Bask1). Ankara: Ankara Üniv. İlahiyat Fak. Yay.

Carullah, Musa (trsz). Kavâid-i Fıkhıyye, Kazan: Örnek Mat.

Fahreddin, Rizaeddin b.(1903), Mütalaa, Petersburg: Kerimov Mat.

Fahreddin, Rizaeddin b., (trsz.), Menasıb-1 Diniyye, Orenburg: Kerimov-Hüseyinov Mat.

Feyizhanoğlu, Abdülallam (1893)., Muharrikü'l-Efkâr, Kazan.

Karaman, Hayrettin (1975), İslam Hukukunda İctihad, Ankara, D.İ.B. Yay., s. 51-80.

Kavanin ve Nizamat-Hukuk-1 Aile Kararnamesi, Ceride-i Ilmiyye, 1334, c. 3, sayı: 24, s. 536-554.

Mardin, Ebu'l-ula (2011). Medeni Hukuk Cephesinden Ahmet Cevdet Paşa, Istanbul Üniversitesi Hukuk Fakültesi Mecmuası, 13 (3), s. 911-940.

Muzafferov, M. Kemal (1912). Medresede Onbeş Yirmi Yıllar Turıp Niler Okudık?, Şûra, 15, s. 474-475. kur,

Okur, Kâşif Hamdi, Ebu Hanife ve Ana Dilde İbadet, İslâmî Araştırmalar, 2002, cilt: XV, sayı: 1-2 [Ebû Hanîfe Özel Sayıs1], s. 83-90.

Ömerî, Abdurrahman (1977). Mecelle-i Ahkâmı Şer'iyye'nin Ailege Aid Kısmı, El Yazma, Abdülhamit Ömerî istinsahı.

Ömerî, Abdurrahman (1926-1928). Mecelle-i Ahkâmı Şer'iyye'nin Ailege Aid Kısmı, El yazma, Abdülhalim Basîrî istinsahı.

Öztürk, Osman (1973). Osmanlı Hukuk Tarihinde Mecelle, İstanbul.

Rahimov; Süleyman (Haz.) (2003). Gabdrahman Gömeri, Kazan: Ruhiyat Neş.

Rusya Müslümanlarının İkinci Umumi Syezdine Mahkeme-i Şer'iye Tarafından Daklad (1917). Ufa.

Şeref, Şeher (Haz.) (1917). Ulema İttifakı Birinci Nedvesi, Kazan: Brat. Kerimov Mat.

\section{АБДУРРАХМАН ОМЕРИ (УМ. 1933) И ЕГО ТРУДЫ В ОБЛАСТИ СЕМЕЙНОГО ПРАВА}

\section{АнНотАцИЯ}

Знаменитый труд «Маджалла-и Ахками Адлие», подготовленный под председательством Ахмета Джевдета-паши, оказал значительное влияние на движение джадидизма в Казанском регионе. Маджалла также использовалась в качестве учебника в некоторых медресе этого региона. Религиозная структура в Казанском регионе не была иерархической, как это было в Османской империи и Туркестане. В царской России мусульмане сами пытались решить свои проблемы, такие как наследство, брак и развод. Имамы в каждом районе 
региона также выполняли обязанности кади. Это в свою очередь вызвало серьезные расхождения в данных правовых заключениях. Поэтому руководство по кодифицированным положениям в османском стиле было необходимо. Основная потребность мусульман Волго-Уральского региона была в сфере семейного права. Принимая это во внимание, мусульмане Волго-Уральского региона утверждали, что новая Маджалла должна быть написана в области семейного права, без привязанности только к одной правовой школе, а с использованием юриспруденции и других правовых школ. Однако в Маджалла, которая была подготовлена под председательством Ахмета Джевдета-паши, не было раздела ог семейном праве. Поэтому при поддержке известного джадидского мыслителя Ризаэддина Фахреддина, Муса Джарулла написал свою работу «Кавайид-и Фикхийе» в стиле Маджалла. 100 из 201 статей в этой книге были взяты из Маджалла Ахмета Джевдета-Паши. Другие статьи были написаны самим Мусой Джаруллахом. Этот труд Мусы Джаруллы не получил широкого признания, потому что он было написан в спешке, также он не был разработан специальной комиссией. По этой причине работа над Маджалла и дальше продолжалась. Однако усилия были безрезультатными до самой большевистской революции.

Попытки написать Маджалла в Казанском регионе продолжились в 1917 году. На съезде мусульманского духовенства в 1917 году, под председательством муфтия того времени Галимджана Баруди, был сформирован консультативный совет при Духовном Управлении в Уфе, и были приняты некоторые решения о том, как написать Маджалла. Кроме того, был создан комитет авторов и определены правила написания Маджалла. Абдуррахман Омери также входил в состав президиума созванного съезда мусульманского духовенства. Таким образом, были предприняты самые серьезные шаги в подготовке Маджалла. Однако в силу условий того периода и эти серьезные шаги оказались безрезультатными. До сих пор не было известно, готовили ли Маджалла в Духовном Управлении в Уфе. Это стало известно после того, как рукописи известного ученого Абдуррахмана Омери, ученика Шихабетдина Марджани, были переданы его наследниками в Национальный архив Татарстана. Мы осуществили классификацию и каталогизацию этого архива. Во время работы мы обнаружили пять рукописей Маджалла по семейному праву, подготовленных Абдуррахманом Омери. Также мы заметили, что эти копии не являются непосредственно рукописями Абдуррахмана Омери и копий, утвержденных Духовным Управлением в Уфе, среди них нет. Из существующих экземпляров два экземпляра состоят из 551 пунктов, другие экземпляры состоят из 405 пунктов, 354 пунктов и последний из 346 пунктов. Дата написания Маджалла Абдуррахманом Омери - 1345 г. по хиджре / 1926 г. по григорианскому календарю. Одна из полных копий была переписана Абдулхамитом Омери, сыном Абдуррахмана Омери, в 1977 году. Согласно предоставленной им информации, вторая полная копия была переписана Абдулхалимом Басири. Абдулхамит Омери взял этот экземпляр за основу для своей собственной копии, но также принял во внимание и другие варианты. Этот экземпляр очень важен, поскольку он включает в себя пункт, добавленный рукой Абдуррахмана Омери. Хотя Абдуррахман Омери написал вначале, что 
Uค• İBrahim Maraș

было 550 пунктов, но с учетом пункта, который он добавил лично, Маджалла состоит из 551 пункта. Согласно информации, предоставленной Абдулхамитом Омери: копия из 354 пунктов была написана Яхьей Хидаятоглу, копия из 405 пунктов была написана Муллой Абдикари Кушмухаммедоглу, а копия из 346 пунктов была написана Хатипом Абдулхамит Моллаоглу. Наша статья будет включать в себя обзор о работах Маджалла в Казанском регионе, ознакомление научного сообщества этими экземплярами Маджалла и краткий анализ их содержания.

Ключевые слова: Маджалла-и Ахкам-и Шерийе, Ахмет Джевдет-паша, Джадидизм, Абдуррахман Омери, Муса Джарулла, Шихабетдин Марджани, семейное право, декрет о семейном праве.

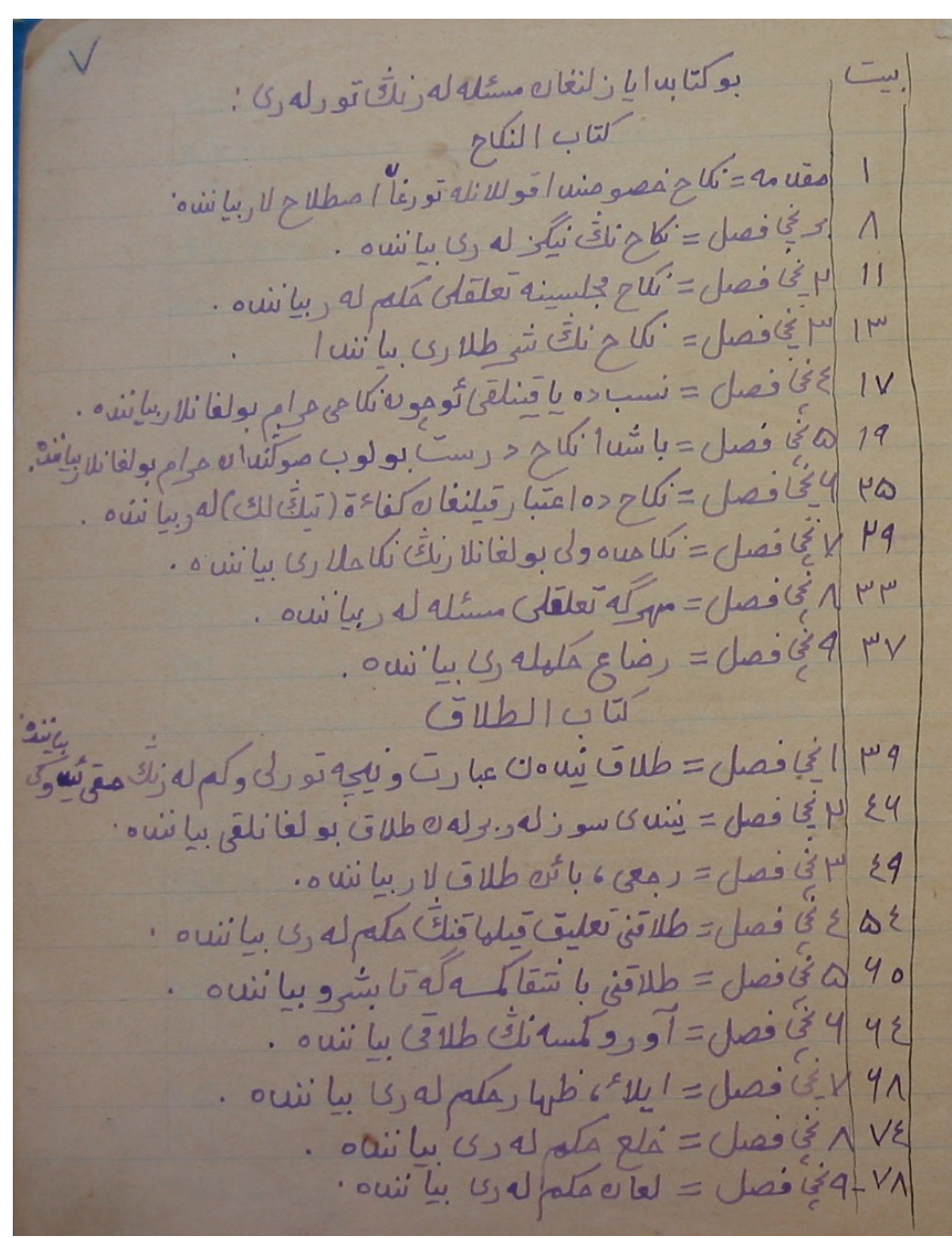


AbdurRahman Ömeri ve Aile Hukukuna Daír Mecelle Çalișmasi • U

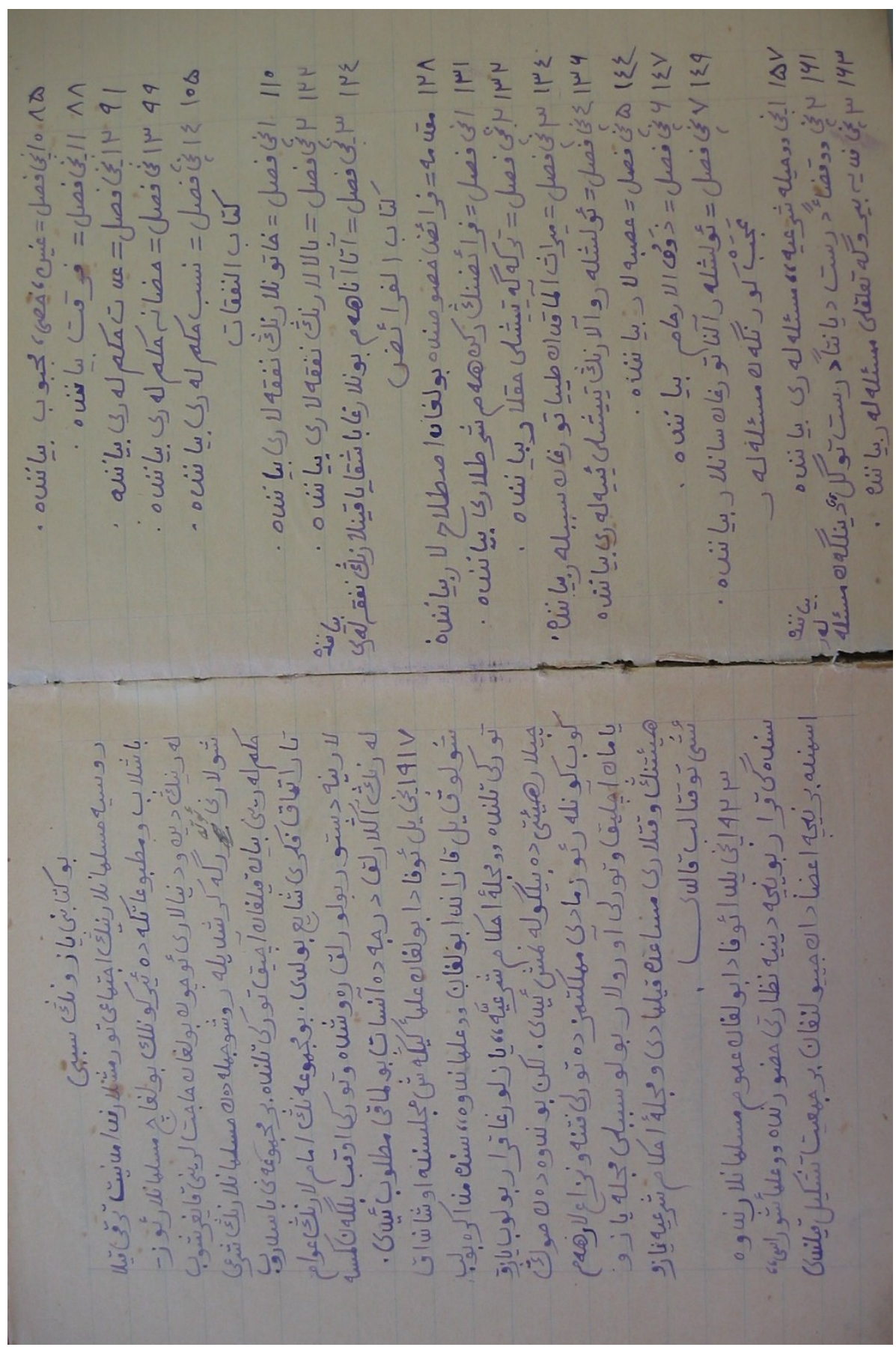

